\title{
Analisis Peramalan dan Periode Ulang Gelombang di Perairan Bagian Timur Pulau Lirang, Maluku Barat Daya
}

\author{
Purwanto $^{(1)}$, Riki Tristanto $^{(1)}$, Gentur Handoyo $^{(1)}$, Mukti Trenggono $^{(2)}$, Agus Anugroho Dwi \\ Suryoputro ${ }^{(1)}$ \\ ${ }^{(1)}$ Program Studi Oseanografi, Fakultas Perikanan dan Ilmu Kelautan, Universitas Diponegoro \\ Jl. Prof. H. Sudarto, SH, Tembalang, Semarang - 50275. Telp/Fax (024) 7474698 \\ ${ }^{(2)}$ Balai Penelitian dan Observasi Laut \\ Jl. Baru Perancak, Negara, Jembrana, Bali - 83351. Telp/0365 44266, Fax. 036544278 \\ E-mail: purwantoirh@yahoo.co.id
}

\begin{abstract}
Abstrak
Pulau Lirang merupakan salah satu pulau terluar Indonesia terletak di Kabupaten Maluku Barat Daya. Terbatasnya data gelombang menjadi salah satu tantangan dalam melakukan perencanaan, pembangunan dan evaluasi di pesisir dan laut. Tujuan penelitian ini adalah menganalisis peramalan dan periode ulang gelombang. Penelitian dilakukan pada 15-19 April 2016 di Perairan Bagian Timur Pulau Lirang menggunakan ADCP Nortex AS Aquadopp Profiler 2000m kedalaman 11,47 meter. Peramalan gelombang diperoleh dari data angin ECMWF dan Ogimet selama 10 tahun (2006-2015). Periode ulang gelombang diperoleh berdasarkan tinggi gelombang signifikan (Hs) melalui peramalan gelombang. Metode penelitian yang digunakan adalah metode survei prediktif dan kuantitatif dengan metode peramalan gelombang Sverdrup Munk Bretschneider (SMB) dan Darbyshire. Tinggi gelombang mencapai 2,672 m (Data ECMWF Metode SMB); 0,251-0,792 m (Data ECMWF Metode Darbyshire); 0,013-2,533 m (Data Ogimet Metode SMB) dan 0,251-6,209 m (Data Ogimet Metode Darbyshire). Tinggi gelombang dari Data ECMWF dengan Metode Darbyshire (MRE maksimum 29,744 \%) lebih sesuai digunakan yaitu tinggi gelombang 0,251-0,79 m dengan periode gelombang 3,663 - 4,717 detik. Periode ulang gelombang dengan metode Weibull memiliki standar deviasi lebih kecil dan tingkat kepercayaan 84,7\%. Periode ulang gelombang dengan metode Weibull lebih sesuai digunakan di Perairan Bagian Timur Pulau Lirang, tinggi gelombang signifikan dengan periode ulang (Hsr) selama 2, 5, 10, 25, 50 dan 100 tahun masing - masing adalah 0,3878 m; 0,4029 m; 0,4166 $\mathrm{m} ; 0,4369 \mathrm{~m} ; 0,4537 \mathrm{~m}$ dan $0,4715 \mathrm{~m}$.
\end{abstract}

Kata kunci: Darbyshire, ECMWF, Ogimet, Periode Ulang, Peramalan Gelombang, Pulau Lirang, SMB

\begin{abstract}
Lirang Island is one of the outer island of Indonesia is located in Southwest Maluku. Lack of wave data into one of the challenges in planning, development and evaluation in the coastal areas and the sea. The purpose of this study was to analyze the forecasting and return wave period. The study was conducted on 15-19 ${ }^{\text {th }}$ April 2016 in the east water of Lirang Island using ADCP Nortex AS Aquadopp Profiler 2000 m, depth 11,47 meters. Forecasting wave wind data obtained from ECMWF and Ogimet for 10 years (2006-2015). Retun wave period is obtained based on the significant wave height (Hs) through wave forecasting. The method of study are predictive survey and quantitative with forecasting method are Sverdrup Munk Bretschneider (SMB) and Darbyshire. High waves reaching 2,672 m (ECMWF Data, SMB method); 0,251-0.792 m (ECMWF Data, Darbyshire method); 0,013 to 2,533 m (Ogimet Data, SMB Method) and 0,251-6,209 m (Ogimet Data, Darbyshire Method). High wave from ECMWF data with Darbyshire method (MRE maximum 29,744\%) are more appropriate, it is high waves 0,2510,79 $\mathrm{m}$ with wave period 3,663-4,717 second. Return wave period with Weibull method has a smaller standard deviation and the confidence level $84,7 \%$. Return wave period with Weibull method is more appropriate to use in the east water of Lirang Island, significant wave height with return period $\left(H_{S R}\right)$ for 2, 5, 10,25, 50 and 100 years are 0,3878 $\mathrm{m} ; 0,4029 \mathrm{~m} ; 0,4166 \mathrm{~m} ; 0,4369 \mathrm{~m} ; 0,4537 \mathrm{~m}$ and 0,4715 $m$.
\end{abstract}

Keywords :, Darbyshire, ECMWF, Lirang Island, Ogimet, Return Period, SMB, Wave Hindscasting, 


\section{Pendahuluan}

Pulau Lirang merupakan salah satu pulau terluar Indonesia yang berada di Kabupaten Maluku Barat Daya. Bagian timur Pulau Lirang memiliki memiliki pemukiman yang terpadat penduduknya diantara seluruh desa yang ada di Pulau Lirang dengan jumlah penduduk 1054 jiwa dengan luas wilayah $39,24 \mathrm{~km}^{2}$. Bagian timur Pulau Lirang menjadi daerah yang sangat strategis karena menjadi pusat aktivitas perekonomian laut. Tidak berfungsinya dermaga menjadi salah satu buruknya pembangunan di Pulau Lirang. Akibatnya bongkar muat dilakukan di tengah laut bagian timur Pulau Lirang. Perahu dan kapal kecil nelayan yang akan melakukan aktivitas pengangkutan penumpang dan barang di laut mendapatkan ancaman bahaya gelombang laut. Mengantisipasi potensi bahaya gelombang diperlukan suatu perencanaan yang baik.

Peraturan Presiden Repulik Indonesia Nomor 33 Tahun 2015 mengenai Rencana Tata Ruang Kawasan Perbatasan Negara di Provinsi Maluku menyebutkan bahwa Pulau Lirang, Kecamatan Wetar Barat termasuk kedalam Kawasan Strategis Nasional yaitu wilayah yang penataan ruangnya diprioritaskan karena mempunyai pengaruh sangat penting secara nasional terhadap kedaulatan negara, pertahanan dan ketahanan negara, ekonomi, sosial, budaya, dan lingkungan (Perpres RI, 2015).

Menurut Thomas dan Dwakarakishb (2015), gelombang yang disebabkan oleh angin adalah bagian penting di daerah pantai dan laut. Informasi gelombang laut dapat diperoleh dengan melakukan pengukuran lapangan namun berbiaya tidak sedikit karena memerlukan peralatan, penguasaan teknologi, pengukuran dalam jangka panjang dan medan lapangan yang tidak mudah. Adanya data angin yang cukup untuk meramal gelombang dengan periode ulang tertentu baik untuk jangka pendek maupun jangka panjang, maka akan diperoleh hasil perencanaan yang optimum, ekonomis dan tepat guna. Tujuan penelitian ini adalah untuk menganalisis peramalan gelombang dengan Metode Sverdrup Munk Bretschneider (SMB) dan Darbyshire menggunakan Data ECMWF dan Ogimet dan menganalisis periode ulang gelombang di Perairan Bagian Timur Pulau Lirang, Maluku Barat Daya.

\section{Materi dan Metode Penelitian Materi}

Materi yang digunakan adalah data yang dibutuhkan dalam penelitian, yaitu data primer dan data sekunder. Data primer meliputi data gelombang pengukuran lapangan selama lima hari pada 15-19 April 2016 di Perairan Bagian Timur Pulau Lirang, Maluku Barat Daya menggunakan ADCP Nortex

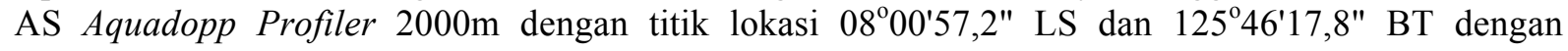
kedalaman 11,47 meter (Peta lokasi penelitian dapat dilihat pada Gambar 2), sedangkan data sekunder yang digunakan meliputi data angin 10 tahun $(2006$ - 2015) diperoleh dari The European Centre for Medium-Range Weather Forecasts (ECMWF) dan Ogimet Information Weather Service dari www.ogimet.com; Peta Rupa Bumi Indonesia Kabupaten Maluku Barat Daya Edisi 1 tahun 2001 skala 1:25.000, Badan Informasi Geospasial (BIG); Citra Google Earth Maluku Barat Daya Perekaman April 2016; dan Citra Landsat 8 perekaman Oktober 2015.

\section{Metode}

Penelitian ini dikategorikan sebagai penelitian dengan metode survei yaitu metode untuk mendapatkan data dari tempat tertentu yang alamiah. Selain itu, penelitian ini menggunakan metode survei prediktif untuk mengestimasi gejala yang mungkin terjadi pada masa mendatang berdasarkan hasil data yang dianalisis saat ini. Analisa data dilakukan dengan pendekatan metode kuantitatif, yaitu metode penelitian yang menggunakan data berupa angka-angka dan analisis menggunakan statistik atau model (Sugiyono, 2009).

\section{Pengukuran Gelombang Laut}

Lokasi pengukuran gelombang menggunakan metode area sampling yaitu metode yang digunakan untuk menentukan lokasi pengukuran apabila daerah pengamatan sangat luas (Sugiyono, 2009). Peralatan pengukuran gelombang diletakkan pada daerah yang dapat dijangkau untuk pengawasan, memperhatikan keselamatan dan sebelum gelombang pecah yang dianggap mampu mewakili kondisi parameter oseanografi pada daerah yang diukur. ADCP Nortex AS Aquadopp Profiller 
2000m pada pengukuran di lokasi penelitian menggunakan frekuensi $600 \mathrm{kHz}$ dengan jangka waktu pencatatan data setiap 1800 detik atau setengah jam. Pengukuran data gelombang lapangan dilakukan untuk mendapatkan parameter gelombang seperti tinggi gelombang $(\mathrm{H})$ dan periode gelombang $(\mathrm{T})$. Alat ini bekerja berdasarkan fluktuasi tekanan yang diterima sensor sehingga diperoleh data gelombang laut (Dean dan Dalrymple, 2000). Data gelombang yang diperoleh dari hasil pengukuran kemudian dianalisis dengan menentukan gelombang representatif.

\section{Data Angin ECMWF}

Peramalan gelombang dengan Data ECMWF berguna untuk memperoleh gelombang representatif dan arah gelombang. Data angin tersebut berupa file .NetCDF diolah dengan menggunakan software $O D V$ 4. Hasilnya berupa data dalam bentuk Text (.txt). Data Text (.txt) ditampilkan di Microsoft Excel dan dikelompokkan sesuai musim sehingga didapat data angin musiman dari tahun 2006-2015. Data angin dianalisis menggunakan perangkat lunak WRPlot View.

\section{Data Angin Ogimet}

Data angin Ogimet diperoleh dari situs www.ogimet.com dengan stasiun pengukuran di Bandara Pulau Alor/Mali dengan ketinggian stasiun 12 meter. Data angin dari ogimet hanya dapat diunduh maksimal satu bulan. Selain itu setelah 3 kali download maka akses untuk download akan bertuliskan limited sehingga perlu 10 - 30 menit untuk mengunduh lagi. Data angin dari Ogimet berupa file text (.txt). Nilai kecepatan dan arah angin pada data Ogimet berada pada kolom kelima sesuai waktu perekaman atau dua kolom setelah kolom stasiun (Ogimet Weather Information Service, 2016).

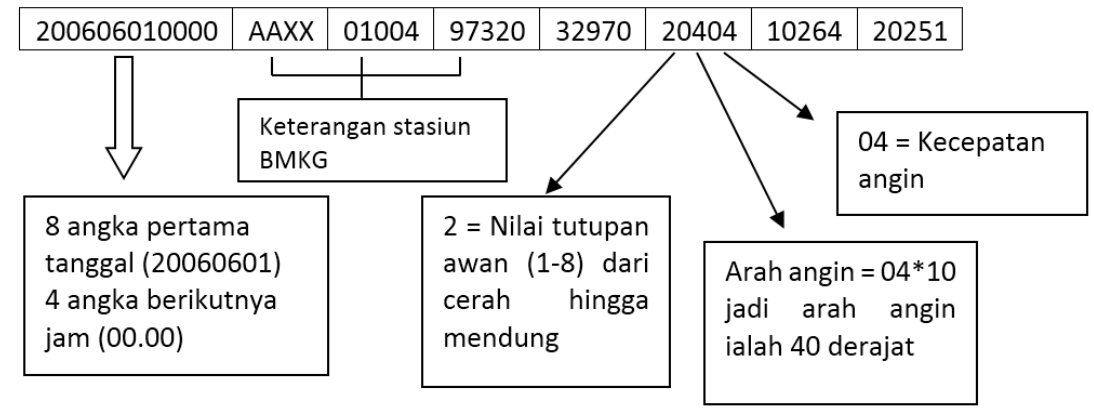

Gambar 1. Diagram Pembacaan Data Ogimet (Land Synoptic Code, 2007)

\section{Metode Sverdrup Munk Bretschneider (SMB)}

Peramalan gelombang dapat disusun berdasarkan significant wave method melalui metode Sverdrup Munk Bretschneider (SMB) yang diperoleh dari data angin (Wibisono, 2011). Metode Sverdrup Munk Bretschneider (SMB) adalah metode yang digunakan untuk mendapatkan nilai tinggi dan periode gelombang laut signifikan. Metode ini lebih baik digunakan daripada menggunakan metode Wilson IV karena melalui metode ini hanya didapatkan ketinggian gelombang laut (Mulyadi, 2015).

\section{Metode Darbyshire}

Darbyshire dan Draper (1963) tepat untuk pendekatan peramalan gelombang perairan dangkal. Tahapan peramalan gelombang dengan metode Darbyshire (Sugianto, 2013) adalah menentukan arah angin menggunakan software windrose (WRPlot View) dan mengklasifikasikan dalam empat kelompok musim (disajikan pada Tabel 1), data angin yang dikelompokkan berdasarkan skala Beaufort meliputi kecepatan angin 11 - 16 knot sebagai angin sedang dan angin kecepatan 17-21 knot digolongkan agak kuat dan kecepatan angin $22-27$ knot sebagai angin kuat; mencari nilai kecepatan angin $\geq 10$ knot sebagai kecepatan maksimum yang dapat membangkitkan gelombang dan melakukan konversi ke satuan $\mathrm{m} / \mathrm{dt}$; Gelombang yang dihasilkan adalah fully developed sea; dan menghitung nilai tinggi dan periode signifikan menggunakan persamaan berikut

(Sugianto, 2013): 


$$
\begin{aligned}
& \mathrm{H}_{\mathrm{S}}=0,0016 \mathrm{U}^{2}+0,0406 \mathrm{U} \\
& \mathrm{T}_{\mathrm{S}}=0,15 \mathrm{U}+2,892
\end{aligned}
$$

Keterangan :

$H_{S}=$ tinggi gelombang signifikan $(\mathrm{m})$

$T_{S}=$ periode gelombang signifikan (detik)

$U=$ kecepatan angin $(\mathrm{m} / \mathrm{s})$

Tabel 1. Pengklasifikasian Musim

\begin{tabular}{lll}
\hline No & \multicolumn{1}{c}{ Nama Musim } & \multicolumn{1}{c}{ Periode } \\
\hline 1 & Musim Barat & Desember - Januari - Februari \\
2 & Musim Peralihan 1 & Maret - April - Mei \\
3 & Musim Timur & Juni - Juli - Agustus \\
4 & Musim Peralihan 2 & September - Oktober - November \\
\hline
\end{tabular}

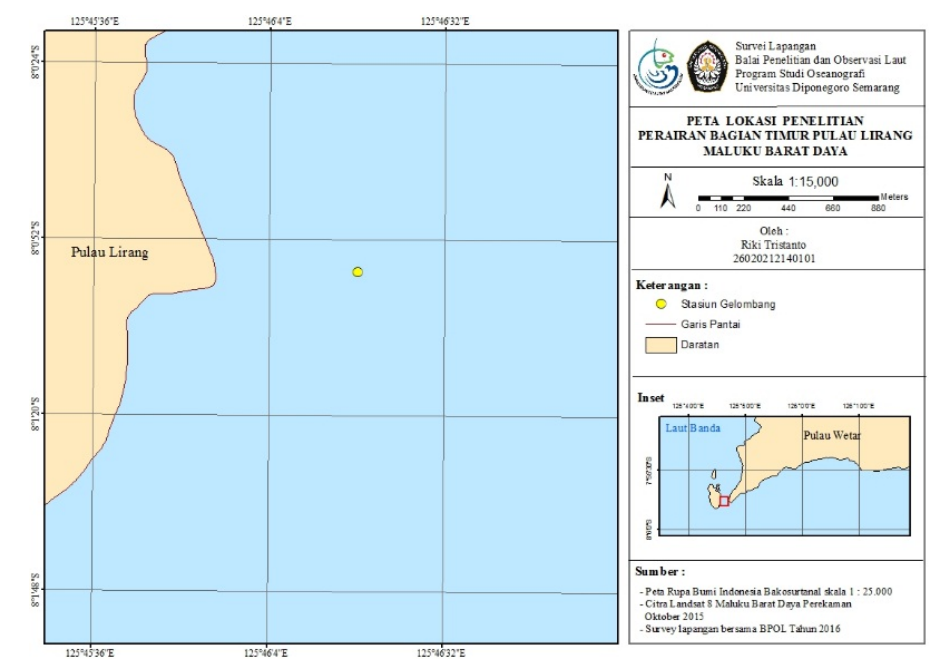

Gambar 2. Peta Lokasi Penelitian

\section{Periode Ulang Gelombang}

Penentuan gelombang dengan periode ulang tertentu dibutuhkan data gelombang dalam jangka waktu pengukuran yang cukup panjang. Data representatif untuk beberapa tahun pengamatan dapat diperkirakan gelombang yang diharapkan disamai atau dilampaui satu kali dalam $\mathrm{T}$ tahun dan gelombang tersebut dikenal dengan gelombang periode ulang $\mathrm{T}$ tahun atau gelombang $\mathrm{T}$ tahunan (Triatmodjo, 1999). Ada dua metode untuk memprediksi gelombang dengan periode ulang tertentu, yaitu metode Gumbel/metode Fisher-Tippet Type I dan metode Weibull (CERC, 1992). Prediksi gelombang dengan periode ulang dapat dihitung dengan fungsi distribusi probabilitas menggunakan metode Gumbel. Gumbel menggunakan harga ekstrim untuk menunjukkan bahwa dalam harga-harga ekstrim mempunyai fungsi distribusi eksponensial ganda (Suripin, 2003). Langkah-langkah memprediksi tinggi gelombang dengan periode ulang gelombang menggunakan metode Weibull hampir sama dengan metode Fisher-Tippet Type I, hanya rumus dan koefisien yang digunakan disesuaikan dengan metode Weibull (CERC, 1992).

\section{Hasil dan Pembahasan Mawar Angin}

Data ECMWF menunjukkan dua arah dominan, yaitu arah selatan dan barat laut dengan kecepatan angin dominan berkisar 7-17 knot, sedangkan data Ogimet menghasilkan dua arah dominan yaitu barat dan timur laut dengan kecepatan angin dominan adalah 0 - 7 knot. Data Ogimet memiliki keberagaman arah lebih tinggi daripada data Ogimet, namun jumlah kecepatan angin dengan kategori tenang (calm) sangat banyak, hal ini dapat dipengaruhi oleh kondisi geografis lokasi pengamatan angin 
dan hambatan aliran angin berupa daratan atau pulau - pulau yang berada di sekitarnya. Data angin Ogimet diperoleh melalui stasiun terdekat dengan lokasi penelitian yaitu di Bandara Pulau Alor (bagian barat Pulau Lirang) dengan ketinggian stasiun $12 \mathrm{~m}$, sedangkan data angin ECMWF diperoleh dari titik terdekat lokasi penelitian yaitu bagian selatan Pulau Lirang.

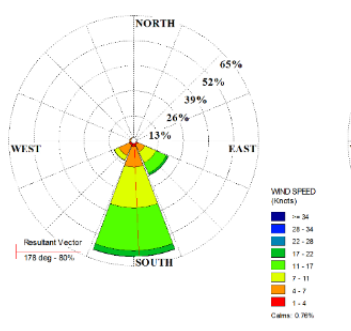

(a)

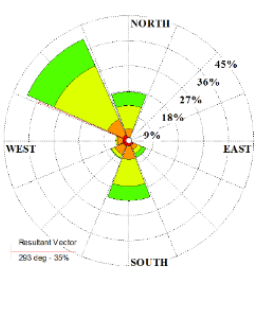

(b)

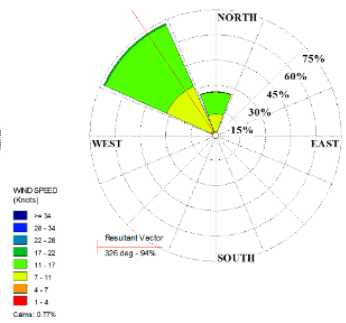

(c)

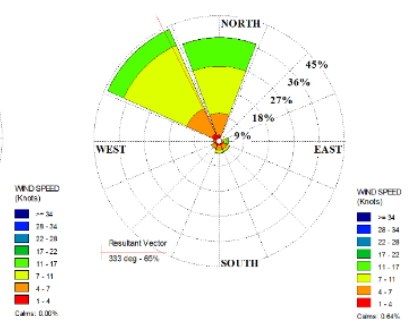

(d)

Gambar 3. Mawar Angin Menggunakan Data ECMWF pada (a) Musim Barat,

(b) Musim Peralihan 1, (c) Musim Timur, (d) Musim Peralihan 2

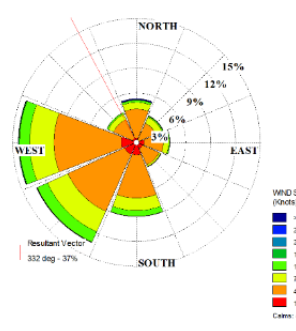

(a)

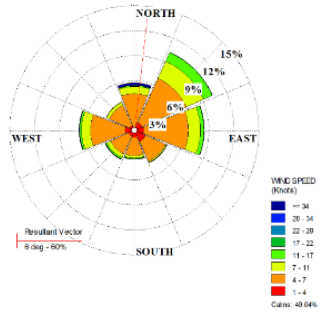

(b)

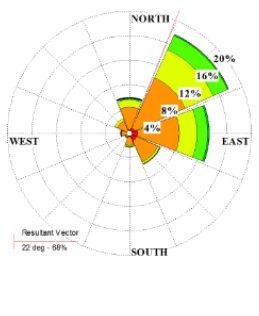

(c)

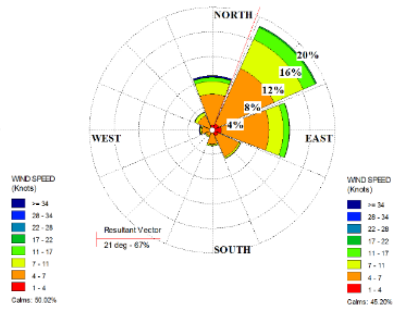

(d)

Gambar 4. Mawar Angin Menggunakan Data Ogimet pada (a) Musim Barat,

(b) Musim Peralihan 1, (c) Musim Timur, (d) Musim Peralihan 2

\section{Peramalan Gelombang}

Tinggi gelombang menggunakan metode SMB lebih tinggi dibandingkan dengan metode Darbyshire dikarenakan metode SMB biasanya digunakan pada daerah lepas pantai dengan faktor kondisi topografi laut diabaikan, sedangkan metode Darbyshire biasanya digunakan didaerah pantai, sehingga apabila metode SMB digunakan di daerah pantai, maka akan menimbulkan kesalahan karena pada daerah pantai kondisi pendangkalan dan topografi laut sangat mempengaruhi karakteristik gelombang dan transfer energi yang membentuk gelombang (CERC, 2006).

Tabel 2. Peramalan Tinggi Gelombang Tiap Musim Menggunakan Data ECMWF

\begin{tabular}{lcccccc}
\hline \multirow{2}{*}{ Musim } & \multicolumn{3}{c}{ Metode SMB } & \multicolumn{3}{c}{ Metode Darbyshire } \\
\cline { 2 - 7 } & Hmax & Hs & Hmin & Hmax & Hs & Hmin \\
\cline { 2 - 7 } & $(\mathrm{m})$ & $(\mathrm{m})$ & $(\mathrm{m})$ & $(\mathrm{m})$ & $(\mathrm{m})$ & $(\mathrm{m})$ \\
\hline Barat & 2,672 & 1,609 & 0,00045 & 0,792 & 0,133 & 0,25096 \\
Peralihan I & 1,293 & 0,795 & 0,22918 & 0,568 & 0,364 & 0,25098 \\
Timur & 1,393 & 1,393 & 0,01461 & 0,731 & 0,405 & 0,25098 \\
Peralihan II & 1,330 & 1,330 & 0,00223 & 0,518 & 0,358 & 0,25097 \\
\hline
\end{tabular}

Peramalan gelombang data Ogimet memiliki perbedaan yang cukup besar terutama pada tinggi gelombang maksimum (Hmax) dan tinggi gelombang minimum (Hmin) antara metode peramalan SMB dan metode peramalan Darbyshire, hal ini dikarenakan ada kecepatan angin dengan nilai yang tidak 
normal pada musim barat, musim timur dan musim peralihan 2, yaitu kecepatan angin mencapai 99 knot atau $50,886 \mathrm{~m} /$ detik.

Tabel 3. Peramalan Periode Gelombang Tiap Musim Menggunakan Data ECMWF

\begin{tabular}{lcccccc}
\hline \multirow{2}{*}{ Musim } & \multicolumn{3}{c}{ Metode SMB } & \multicolumn{3}{c}{ Metode Darbyshire } \\
\cline { 2 - 7 } & Tmax & Ts & Tmin & Tmax & Ts & Tmin \\
\cline { 2 - 7 } & (detik) & (detik) & (detik) & (detik) & (detik) & (detik) \\
\hline Barat & 6,676 & 5,622 & 0,111 & 3,663 & 3,713 & 4,8307 \\
Peralihan I & 4,511 & 3,814 & 0,229 & 4,397 & 3,944 & 3,6631 \\
Timur & 4,625 & 4,625 & 0,567 & 4,717 & 4,039 & 3,6631 \\
Peralihan II & 4,554 & 4,554 & 0,439 & 4,290 & 3,930 & 3,6630 \\
\hline
\end{tabular}

Tabel 4. Peramalan Tinggi Gelombang Tiap Musim Menggunakan Data Ogimet

\begin{tabular}{lcccccc}
\hline \multirow{2}{*}{ Musim } & \multicolumn{3}{c}{ Metode SMB } & \multicolumn{3}{c}{ Metode Darbyshire } \\
\cline { 2 - 7 } & Hmax & Hs & Hmin & Hmax & Hs & Hmin \\
\cline { 2 - 7 } & $(\mathrm{m})$ & $(\mathrm{m})$ & $(\mathrm{m})$ & $(\mathrm{m})$ & $(\mathrm{m})$ & $(\mathrm{m})$ \\
\hline Barat & 2,533 & 0,115 & 0,0131 & 6,209 & 0,765 & 0,251 \\
Peralihan I & 1,409 & 0,373 & 0,0216 & 0,281 & 0,389 & 0,281 \\
Timur & 2,311 & 0,726 & 0,0216 & 6,002 & 0,489 & 0,251 \\
Peralihan II & 2,205 & 0,685 & 0,0199 & 5,899 & 0,735 & 0,251 \\
\hline
\end{tabular}

Tabel 5. Peramalan Periode Gelombang Tiap Musim Menggunakan Data Ogimet

\begin{tabular}{lcccccc}
\hline \multirow{2}{*}{ Musim } & \multicolumn{3}{c}{ Metode SMB } & \multicolumn{3}{c}{ Metode Darbyshire } \\
\cline { 2 - 7 } & Tmax & Ts & Tmin & Tmax & Ts & Tmin \\
\cline { 2 - 7 } & (detik) & (detik) & (detik) & (detik) & (detik) & (detik) \\
\hline Barat & 1,901 & 1,083 & 0,5499 & 10,525 & 4,563 & 3,663 \\
Peralihan I & 4,838 & 2,336 & 0,5549 & 3,740 & 3,927 & 3,740 \\
Timur & 5,381 & 3,809 & 0,5499 & 10,371 & 4,186 & 3,663 \\
Peralihan II & 5,381 & 3,725 & 0,5499 & 10,294 & 4,481 & 3,663 \\
\hline
\end{tabular}

\section{Gelombang Lapangan}

Hasil pengukuran gelombang lapangan secara umum relatif kecil, hal ini terjadi karena pada saat pengukuran data lapangan dilakukan pada pertengahan bulan April yang termasuk kedalam musim peralihan I, hal ini sesuai dengan pernyataan (Kurniawan et al., 2011) bahwa kondisi kecepatan angin rendah di atas perairan Indonesia pada musim peralihan sehingga gelombang laut lebih rendah. Pada musim peralihan, posisi matahari berada di sekitar wilayah ekuator, dengan demikian gradien suhu antara Asia dan Australia tidak besar sehingga kecepatan aliran angin dari kedua benua yang melintasi Indonesia rendah. Berdasarkan pengolahan data angin pada saat musim peralihan 1, angin berhembus dengan arah dominan dari Barat Laut (ECMWF), sedangkan angin berhembus dengan arah dominan dari Timur Laut (Ogimet). Hal ini mengakibatkan hembusan angin banyak terhalang oleh daratan, yaitu Pulau Lirang, Pulau Wetar dan Pulau Babi. Selain itu, lokasi pengukuran gelombang berada di bagian Selat Wetar dan dekat dengan daratan menyebabkan gaya pembangkit angin menjadi kecil karena diredam oleh daratan.

Klasifikasi gelombang Perairan Bagian Timur Pulang Lirang berdasarkan kedalaman relatif termasuk gelombang laut transisi karena memiliki nilai d/L diantara $1 / 20$ dan $1 / 2$ yaitu 0,465 . Holthuijsen (2007), menjelaskan bahwa kedalaman relatif dengan perbandingan antara kedalaman perairan (d) dan panjang gelombang (L) dengan nilai diantara $1 / 20$ dan $1 / 2$ adalah gelombang laut transisi. Berdasarkan gaya pembangkit gelombang yang terbentuk, pada lokasi penelitian dikategorikan sebagai gelombang 
yang dibangkitkan oleh angin karena memiliki periode gelombang berkisar 3,23-4,93 detik. Hal ini menunjukkan bahwa gelombang yang terbentuk di Perairan Pulau Lirang, karakteristiknya sangat dipengaruhi oleh kondisi angin. Klasifikasi gelombang berdasarkan periode yaitu gelombang gravitasi memiliki periode 1 detik sampai 30 detik. Gelombang gravitasi merupakan gelombang yang dipengaruhi oleh gravitasi bumi dan daya apung air (WMO, 1998).

Tabel 6. Tinggi (H) dan Periode (T) Gelombang Harian Pengukuran Lapangan

\begin{tabular}{ccccccc}
\hline Tanggal & $\begin{array}{c}\text { Hmax } \\
(\mathrm{m})\end{array}$ & Hs $(\mathrm{m})$ & $\begin{array}{c}\text { Hmin } \\
(\mathrm{m})\end{array}$ & $\begin{array}{c}\text { Tmax } \\
(\mathrm{dt})\end{array}$ & $\begin{array}{c}\text { Ts } \\
(\mathrm{dt})\end{array}$ & Tmin $(\mathrm{dt})$ \\
\hline 15 - 19 April 2016 & 0,46 & 0,244 & 0,06 & 4,93 & 3,996 & 3,23 \\
15 April 2016 & 0,46 & 0,108 & 0,07 & 3,94 & 3,695 & 3,28 \\
16 April 2016 & 0,45 & 0,276 & 0,09 & 4,93 & 3,553 & 3,26 \\
17 April 2016 & 0,46 & 0,172 & 0,07 & 4,29 & 3,618 & 3,23 \\
18 April 2016 & 0,14 & 0,085 & 0,06 & 4,43 & 3,922 & 3,33 \\
19 April 2016 & 0,12 & 0,1 & 0,06 & 3,92 & 3,6 & 3,33 \\
\hline
\end{tabular}

Secara umum, hasil yang diperoleh dari data pengukuran lapangan belum dapat menggambarkan kondisi gelombang secara keseluruhan berdasarkan kondisi musim. Hal ini disebabkan oleh pengaruh musim dan angin yang bertiup pada saat pengukuran yang dilakukan hanya beberapa hari dalam satu musim, yaitu musim peralihan I. Pendekatan yang dapat dilakukan adalah dengan melakukan peramalan gelombang angin dalam jangka waktu tertentu. Tinggi dan periode gelombang harian pengukuran lapangan dapat dilihat pada Tabel 6 .

\section{Validasi Hasil}

Peramalan gelombang angin memerlukan validasi terhadap data gelombang lapangan untuk mengetahui tingkat akurasi melalui pendekatan dengan data objektif. Validasi dilakukan dengan menghitung kesalahan relatif dan rata - rata kesalahan relatif atau mean relatif error (MRE). Metode Darbyshire dengan data masukan dari data angin ECMWF lebih sesuai dengan peramalan gelombang di Perairan Bagian Timur dikarenakan memiliki nilai MRE terkecil dan kurang dari $50 \%$. Menurut Purwanto (2011), menyatakan bahwa nilai kesalahan relatif yang tidak melebihi $50 \%$ tidak bermasalah walaupun mengalami sedikit perbedaan. Validasi hasil peramalan gelombang dengan Metode Darbyshire dan SMB disajikan pada Tabel 7 dan 8.

Tabel 7. Validasi Hasil Peramalan Gelombang Metode Darbyshire

\begin{tabular}{|c|c|c|c|c|c|c|}
\hline & & $\mathrm{Hs}$ & MRE & Ts & MRE \\
\hline & & & $(\mathrm{m})$ & $(\%)$ & $(\mathrm{dt})$ & $(\%)$ \\
\hline \multirow{11}{*}{ 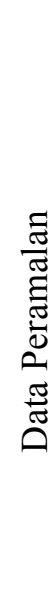 } & Data Lapangan & & 0,244 & & 3,996 & \\
\hline & 2006 & \multirow{10}{*}{$\sum_{\text {II }}^{\sum_{I}^{L}}$} & - & - & - & - \\
\hline & 2007 & & 0,269 & 10,234 & 3,710 & 7,159 \\
\hline & 2008 & & 0,278 & 13,857 & 4,657 & 16,550 \\
\hline & 2009 & & - & - & - & - \\
\hline & 2010 & & - & - & - & - \\
\hline & 2011 & & - & - & - & - \\
\hline & 2012 & & - & - & - & - \\
\hline & 2013 & & - & - & - & - \\
\hline & 2014 & & 0,308 & 26,313 & 3,810 & 4,667 \\
\hline & 2015 & & 0,317 & 29,744 & 3,925 & 1,767 \\
\hline
\end{tabular}




\begin{tabular}{|c|c|c|c|c|c|}
\hline $2006-2015$ & & 0,269 & 10,405 & 3,711 & 7,134 \\
\hline 2006 & \multirow{11}{*}{ 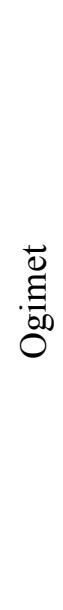 } & - & - & - & - \\
\hline 2007 & & - & - & - & - \\
\hline 2008 & & - & - & - & - \\
\hline 2009 & & - & - & - & - \\
\hline 2010 & & - & - & - & - \\
\hline 2011 & & - & - & - & - \\
\hline 2012 & & 0,625 & 156,005 & 4,511 & 12.890 \\
\hline 2013 & & - & - & - & - \\
\hline 2014 & & 1,384 & 467,144 & 5,552 & 38,938 \\
\hline 2015 & & 0,295 & 21,309 & 3,778 & 5,439 \\
\hline $2006-2015$ & & 0,950 & 289,391 & 4,916 & 23,020 \\
\hline
\end{tabular}

\section{Periode Ulang Gelombang}

Secara statistik, probabilitas nilai gelombang dengan kala ulang tertentu dapat dipengaruhi oleh adanya panjang atau jumlah data yang tersedia. Dengan semakin banyak jumlah data maka hasil yang diperoleh akan lebih baik. Umumnya, nilai tinggi gelombang dengan kala ulang akan meningkat sesuai dengan pertambahan tahun. Tinggi gelombang (Hsr) untuk 100 tahun akan lebih tinggi daripada tinggi gelombang untuk 50 tahun. Tinggi gelombang (Hsr) 50 tahun akan lebih tinggi daripada tinggi gelombang untuk 25 tahun dan seterusnya (dapat ditunjukkan melalui Gambar 5). Peningkatan tinggi gelombang signifikan periode ulang sangat ditentukan oleh jumlah kejadian gelombang dan nilai periode ulang. Dengan semakin tinggi jumlah kejadian dan periode ulang tertentu, maka tinggi gelombang signifikan akan semakin besar begitupun sebaliknya.
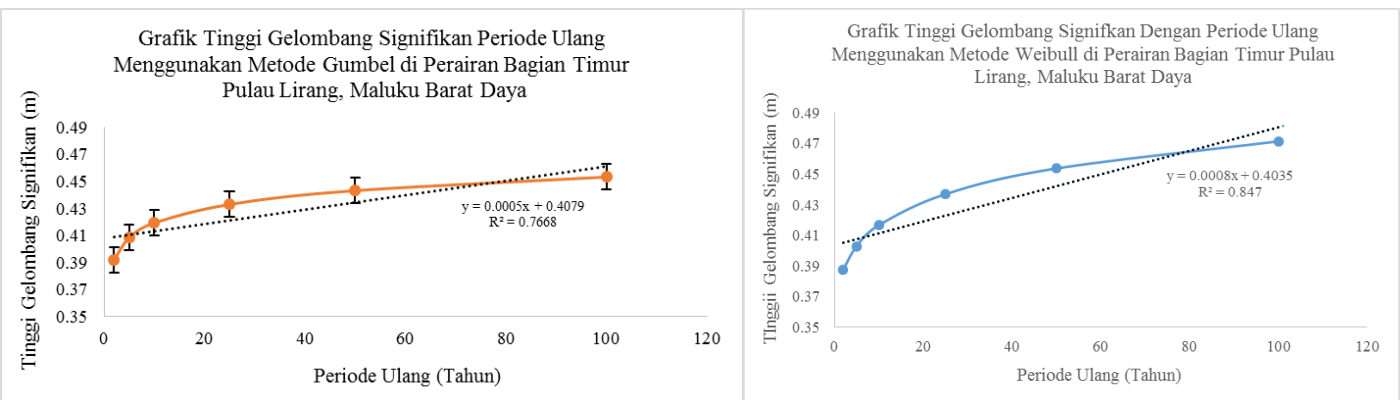

Gambar 5. Tinggi Gelombang Signifikan dengan Periode Ulang Gelombang

Periode ulang dengan metode Weibull memiliki standar deviasi lebih kecil daripada metode Gumbel (Fisher - Tippet Type I) dan tingkat kepercayaan berdasarkan persamaan linier mencapai 84,7 $\%$ lebih tinggi dibandingkan metode Gumbel, hal ini membuktikan bahwa metode Weibull lebih sesuai digunakan pada penelitian periode ulang di Perairan Bagian Timur Pulau Lirang, Maluku Barat Daya.

Tabel 8. Validasi Hasil Peramalan Gelombang Metode SMB

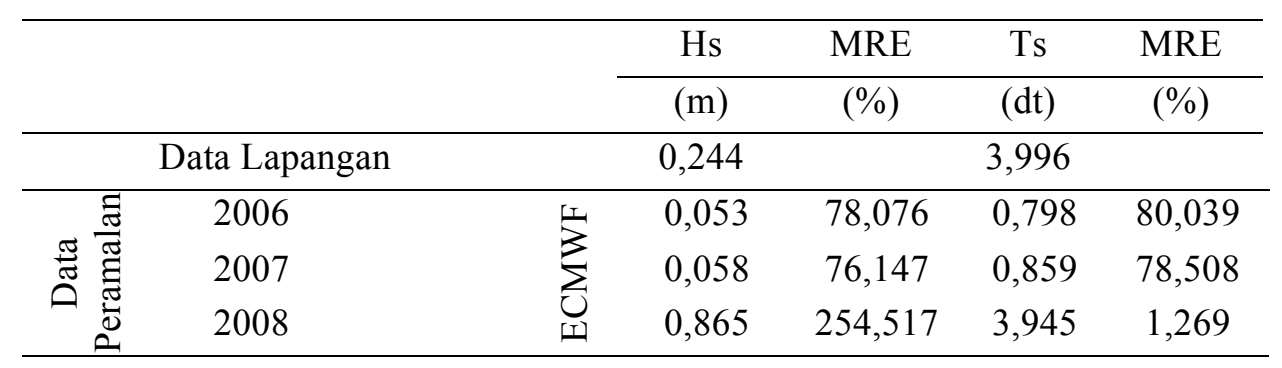




\begin{tabular}{|c|c|c|c|c|c|}
\hline 2009 & & 0,134 & 45,073 & 1,492 & 62,671 \\
\hline 2010 & & 0,049 & 79,782 & 0,702 & 82,420 \\
\hline 2011 & & 0,047 & 80,589 & 0,626 & 84,324 \\
\hline 2012 & & 0,664 & 172,307 & 3,610 & 9,655 \\
\hline 2013 & & 0,107 & 56,177 & 1,054 & 73,622 \\
\hline 2014 & & 0,046 & 81,123 & 0,627 & 84,321 \\
\hline 2015 & & 0,117 & 52,217 & 1,279 & 67,993 \\
\hline $2006-2015$ & & 0,347 & 42,065 & 2,146 & 46,308 \\
\hline 2006 & & 0,169 & 30,940 & 1,577 & 60,543 \\
\hline 2007 & & 0,248 & 1,694 & 1,490 & 62,709 \\
\hline 2008 & & 0,333 & 36,617 & 2,449 & 38,723 \\
\hline 2009 & & 0,042 & 82,632 & 0,626 & 84,336 \\
\hline 2010 & & 0,106 & 56,610 & 0,683 & 82,909 \\
\hline 2011 & 施 & - & - & - & - \\
\hline 2012 & & - & - & - & - \\
\hline 2013 & & - & - & - & - \\
\hline 2014 & & - & - & - & - \\
\hline 2015 & & - & - & - & - \\
\hline $2006-2015$ & & 0,184 & 24,794 & 1,385 & 65,344 \\
\hline
\end{tabular}

\section{Kesimpulan}

Berdasarkan penelitian yang telah dilakukan dapat disimpulkan bahwa tinggi gelombang mencapai 2,672 m (Data ECMWF Metode SMB); 0,251- 0,792 m (Data ECMWF Metode Darbyshire); 0,013 - 2,533 m (Data Ogimet Metode SMB) dan 0,251- 6,209 m (Data Ogimet Metode Darbyshire). Data ECMWF dengan Metode Darbyshire (maksimum MRE 29,744 \%) lebih sesuai digunakan yaitu tinggi gelombang 0,251 - 0,792 m dengan periode gelombang 3,663 - 4,717 detik. Periode ulang dengan metode Weibull memiliki standar deviasi lebih kecil, sehingga lebih sesuai digunakan di Perairan Bagian Timur Pulau Lirang, Maluku Barat Daya. Metode Weibull menghasilkan tinggi gelombang dengan periode ulang gelombang (Hsr) 2, 5, 10, 25, 50 dan 100 tahun, yaitu 0,3878 m; 0,4029 m;0,4166 $\mathrm{m} ; 0.4369 \mathrm{~m} ; 0,4537 \mathrm{~m}$ dan $0,4715 \mathrm{~m}$.

\section{Daftar Pustaka}

CERC. 2006. Coastal Engineering Manual. US Army Coastal Engineering Research Center, Washington.

1992. Automated Coastal Engineering System. Departement of the Army Water-way Experiment Station Corps of Engineers, Missisipi.

Darbyshire, M. and Draper, L. 1963. Forecasting Wind - Generated Sea Waves, National Institute of Oceanography, Wormley, Surrey, England, published in Engineering.

Dean, R.G and Dalrymple, R.A. 2000. Water Wave Mechanics for Engineers and Scientists. World Scientific Publishing, Singapore.

Holthuijsen, L. 2007. Wave in Oceanic and Coastal Waters. Cambridge University Press, New York. Kurniawan, R., Habibie, M.N. dan Suratno. Variasi Bulanan Gelombang Laut Indonesia. 2011. Jurnal Meteorologi Dan Geofisika., 12 (3): 221 - 232.

Land Synoptic Code. 2007. Land Station Surface Synoptic Code FM 1-IX Synop

Mulyadi, J. dan Apriansyah. 2015. Studi Variabilitas Tinggi dan Periode Gelombang Laut Signifikan di Selat Karimata. Positron., V(1): $19-25$. 
Ogimet Weather Information Service. 2016. Synop Reports of Alor Station. http://www.ogimet.com (29 Maret 2016).

Perpres RI. 2015. Rencana Tata Ruang Kawasan Perbatasan Negara di Provinsi Maluku. Peraturan Presiden RI Nomor 33 Tahun 2015, Jakarta.

Purwanto. 2011. Analisa Spektrum Gelombang Berarah di Pantai Kuta, Kabupaten Badung Bali. Jurnal Buletin Oseanografi Marina, 1: 45 - 59.

Sugianto, D.N. 2013. Model Distribusi Data Kecepatan Angin dan Pemanfaatannya dalam Peramalan Gelombang di Perairan Laut Jawa. Program Doktor Teknik Sipil, FT Undip, Semarang.

Sugiyono. 2009. Metode Penelitian Kuantitatif dan Kualitatif. Alfabeta, Bandung.

Suripin. 2003. Sistem Drainase Perkotaan yang Berkelanjutan. Andi, Yogyakarta.

Thomas, Justin and Dwarakishb, G.S. 2015. International Conference on Water Resources. Coastal and Ocean Engineering, Department Of Applied Mechanics And Hydraulics, Nitk Surathkal, Mangalore, Karnataka India Aquatic Procedia 4: 443 - 448.

Triatmodjo, Bambang. 1999. Teknik Pantai. Beta Offset, Yogyakarta.

Wibisono, M.S. 2011. Pengantar Ilmu Kelautan. Ed.2., UI Press, Jakarta.

WMO (World Meteorology Organization). 1998. Guide To Wave Analysis And Forecasting. $1^{\text {st }}$ ed., Geneva, Switzerland. 